\title{
UPAYA PENINGKATAN PROSES BELAJAR ATLETIK TOLAK PELURU MELALUI PENERAPAN MEDIA POA PADA SISWA KELAS V SD NEGERI 05 KOTA BENGKULU
}

\author{
Nuryati \\ Universitas Bengkulu \\ nurhayati@gmail.com \\ Arwin \\ Universitas Bengkulu \\ Bogy Restu Ilahi \\ Universitas Bengkulu
}

\begin{abstract}
Abstrak
Penelitian ini bertujuan untuk mengetahui peningkatan proses belajar atletik tolak peluru. Media yang dipakai adalah bola peralatan olahraga anak (POA). Jenis Penelitian adalah penelitian tindakan kelas. Penelitian dilakukan pada siswa kelas V SD Negeri 05 Kota Bengkulu yang berjumlah 35 siswa. Pada penelitian ini melihat hasil uji pra siklus, siklus 1, 2 dan siklus 3 serta lembar observasiguru dan siswa. Nilai tes uji pra siklus di dapat $31,1 \%$ yang mendapat nilai cukup artinya masih sangat kurang dalam proses belajar atletik tolak peluru. Pada siklus 1 di dapat $40 \%$ terjadi peningkatan proses belajar tolak peluru pada media POA namun belum mencapai KKM dan dilihat dari observasi gurumendapatnilai 40\%danobservasisiswa 40\%.Padasiklus 2 didapatnilaites sebesar $65,7 \%$, sedangkan lembar observasi guru sebesar $66 \%$ dan lembar observasi siswa sebesar $60 \%$ belum tuntas belajar. Pada siklus 3 ketuntasan belajar siswa mencapai $85,7 \%$ sedangkan lembar observasi guru mencapai $80 \%$ dan lembar obsevasi siswa mencapai 76\% semua telah menunjukan ketuntasan nilai atau KKM 70\%. Dari nilai tes siklus 3 dapat disimpulkan pembelajaran tolak peluru dengan menggunakan model pembelajaran bola POA dapat meningkatkan proses belajar atletik tolak peluru dan meningkatkan semangat belajar siswa. Peningkatan ini dikarenakan siswa bersemangat dalam proses belajar dan saling membantu di dalam kelompok masing.
\end{abstract}

Kata kunci: Atletik, Tolak Peluru, Media POA, Penerapan

\section{Abstract}

This study aims to determine the improvement of learning process of athletic shot put. The media used is a child's sports ball (POA). Type of research is a classroom action research. The research was conducted on the students of class V SD Negeri 05 City of Bengkulu which amounted to 35 students. This study looks at the results of pre-cycle test, cycles 1, 2 and 3 cycles and teacher and student observation sheets. The value of precycle test test in $31.1 \%$ can get enough value means still very less in the learning process of athletic shot put. In the 1 st cycle in $40 \%$ can be increased learning process of putting a shoton the POA media but notyetreached KKMand viewed from the observation of teachers get a score of $40 \%$ and $40 \%$ student observation. In cycle 2 got the test value of $65,7 \%$, while the observation sheet of teacher equal to $66 \%$ and student observation sheet of $60 \%$ unfinished study. In cycle 3, students' learning completeness reaches $85.7 \%$ while teacher observation sheet reaches $80 \%$ and obsevation sheet of students reaches $76 \%$ all have shown mastery value or KKM $70 \%$. From the value of the testcycle 3 can be 
concluded the learning of a shot put by using the POA ball learning model can improve the learning process of athletic hit and increase the spirit of learning students. This increase is because students are eager in the learning process and help each other in their group.

Keywords: Athletic, Shot Put, POA Media, Implementation

\section{PENDAHULUAN}

Pendidikan jasmani pada dasarnya bertujuan mengembangkan keterampilan gerak siswa dalam pembelajaran yang diartikan bahwa guru pendidikan jasmani dalam pelajaran harus banyak memberikan konsep-konsep pengembangan gerak. Hal ini di kemukakan oleh Sugiyanto (1990:15), pada dasarnya keterampilan gerak harus diberikan kepada anak didik harus berdasarkan pada: a) gerak Lokomotor, b) gerak nonLokomotor, dan gerak Manipulatif.

Menurut Dini Rosdiani (2013:137) "Pendidikan jasmani adalah proses pendidikan yang memanfaatkan aktifitas jasmaniyang direncanakan secara sistematik bertujuan untuk mengembangkan dan meningkatkan individu secara organik, neuromuskular, perseptual, kognitif, dan emosional, dalam kerangka pendidikan nasional. Belajar merupakan suatu proses yang ditandai dengan adanya perubahan pada diri seorang. Perubahan ini sebagai hasil dariproses belajar dapat ditunjukkan dalam berbagai bentuk seperti berubah pengetahuan, pemahaman, sikap, dan tingkah laku, keterampilan kecakapan, kebiasaan serta perubahan aspekaspeklain yang adapada individu yang belajar. Sementara itu peranan siswa dalam proses belajar mengajar adalah suatu proses yang di alami siswa di sekolah dalam mencari atau menambah pengetahuan, pengalaman dan sikap.

Berkaitan dengan pemerintah menggariskan dalam Undang-Undang No.20 Tahun 2003 pasal 1 (2010:9) tentang sistem pendidikan Nasional yang dinyatakan sebagai: "usaha sadar untuk menciptakan suasana belajar dan proses pembelajaran agar peserta didik secara aktif mengembangkan potensi dirinya untuk memiliki kekuatan spiritual keagamaan, pengendalian diri, kepribadian, kecerdasan, ahlak mulia, serta keterampilan yang diperlukan oleh dirinya, masyarakat bangsa dan Negara".

Strategi pembelajaran sangat komplek karena harus disesuaikan dengan perkembangan anak yang intinya sangat menyenangkan kegiatan pendidikan jasmani yang termasuk dalam dunia bermain sesuai jiwa anak dan perkembangannya.

Selain itu, kegiatan pendidikan jasmani juga berpengaruh terhadap karakteristik setiap individu termasuk pada anak sekolah dasar mereka menampilkan perbedaanperbedaan individual dalam banyak segi dan bidang, diantaranya, perbedaan dalam intelegensi, kemampuan dalam kognitif dan bahasa, perkembangan kepribadian dan perkembangan fisik anak. Menurut Erikson perkembangan psikososial pada usia enam sampai pubertas, anak mulai memasuki dunia pengetahuan dan dunia kerja yang luas. Peristiwa penting pada tahap ini anak mulai masuk sekolah, mulai dihadapkan dengan tekhnologi masyarakat, di samping itu proses belajar mereka tidak hanya terjadi di sekolah. Adapun juga karakteristik pada siswa sekolah dasar dalam bidang pendidikan jasmani olahraga.

Pelaksanaan proses pembelajaran pendidikan jasmani di sekolah khususnya SD Negeri 5 Kota Bengkulu masih belum optimal karena terbatasnya waktu yang tersedia serta sarana dan prasarana disekolah. Oleh karena itu diperlukan upaya-upaya perbaikan dalam proses pembelajaran seperti pemilihan media yaang sangat tepat, dan memenuhisyarat. 
Pada saat proses pembelajaran pendidikan jasmani olahraga dan kesehatan di SD Negeri 05 Kota Bengkulu, diharapkan dapat menciptakan interaksi yang baik antara guru dengan siswa antara siswa dengan siswa secara maksimal, hal ini sangat penting untuk menghidupkan suasana dalam belajar. Guru berperan sebagai pengelola proses pembelajaran, bertindak selaku fasilitator sehingga memungkinkan terjadinya proses pembelajaran.

Teknik yang harus dikuasai dalam melakukan tolak peluru adalah cara memegang peluru, tehnik meletakkan peluru, persiapan awal, awalan sikap badan akan menolak, dan cara menolakkan peluru. gaya tolak peluru ini terbagi menjadi dua jenis yaitu: gaya menyamping (Ortodoks) dan gaya membelakangi (O'briens).

Berdasarkan pengalaman peneliti mengajarkan tehnik tolak peluru di kelas V SD Negeri5KotaBengkulu dari35 siswayang bisa melakukan hanya 10 siswa dan 25 siswa dinyatakan belum tuntas. Guru hanya mengunakan sistem pembelajaran yang bersifat satu arah dalam menjelaskan gerakan tolak peluru dan kurang melibatkan siswa, sehingga siswa kurang termotivasi untuk mengikuti pelajaran. akibatnya gerakan dasar tolak peluru yang dilakukan siswa kurang tepat, seperti sikap pada waktu memegang tolak peluru, posisi kaki, dan tolakan tidak tepat pada sasaran. Jadi, jelas bahwa pembelajaran yang dilaksanakan selama ini cendrung kurang melibatkan siswa di dalamnya sehingga siswa kurang termotivasi dalam praktik tolak peluru dan hasil belajar siswapun kurangmemuaskan.

Menindak lanjuti permasalahan diatas guru harus mencari alternatif yang menarik minat dan motivasi siswa, yakni dengan menggunakan media POA. Berdasarkan pernyataan diatas peneliti akan melakukan Penelitian Tindakan Kelas (PTK) dengan judul penelitian "Upaya Peningkatan Proses Belajar Atletik Tolak Peluru Melalui Penerapan Media POA Pada Siswa Kelas V SD Negeri 5 Kota
Bengkulu". Tujuan dari penelitian ini adalah Untuk dapat meningkatkan proses belajar atletik tolak peluru pada siswa kelas V SD Negeri 05 Kota Bengkulu melalui media POA.

\section{METODE}

Jenis penelitian yang dilakukan pada peneliti ini adalah penelitian tindakan kelas. Penelitian tindakan berasal dari istilah classroom action research dengan kata lain penelitian tindakan adalah cara suatu kelompok atau sesorang dalam suatu kondisi sehingga mereka dapat mempelajari pengalaman mereka dan membuat pengalaman mereka dapat diakses oleh orang lain sukardi (2003:210).

Penelitian Tindakan Kelas memiliki peranan yang sangat penting dan strategis untuk meningkatkan mutu pembelajaran apabila di implementasikan dengan baik dan benar. Di implementasikan dengan baik, artinya pihak yang terlibat dalam PTK (guru) mencoba dengan sadar mengembangkan kemampuan dalam mendeteksi dan memecahkan masalah-masalah yang terjadi dalam pembelajaran dikelas melalui tindakan bermakna yang diperhitungkan dapat memecahkan masalah atau memperbaiki situasi dan secara cermat mengamati pelaksanaannya untuk mengukur tingkat keberhasilan pembelajaran yang di selenggarakan secaraprofesional.

Dari pengertian diatas dapat ditarik kesimpulan bahwa PTK merupakan suatu penelitian yang dilaksanakan suatu kelas atau objek peneliti saja dengan tujuan peningkatan atau perbaikan praktek pembelajaran, pengembangan keterampilan guru berdasarkan persoalan yang dihadapi oleh guru dan meningkatkan hasil belajar.

Dalam penelitian tindakan kelas harus berorientasi juga pada prosesnya, bukan pada hsil belajarnya saja. Hal ini dikarenakan hasil yang baik akan ditentukan oleh proses yang baik pula. Ada empat tahapan penting dalam melaksanakan penelitian tindakan kelas yakni: 
1) Perencanaan, 2) Pelaksanaan, 3) Pengamatan, 4) Refleksi Kunandar (2011:41,42).

Lokasi penelitian adalah tempat dimana akan melakukan penelitian Penelitian ini dilakukan di Kelas V SDN 5 Kota Bengkulu. Penelitian ini akan dilaksanakan di kelas V SD Negeri 5 Kota Bengkulu pada mata pelajaran Penjaskes dengan materi proses belajar atletik tolak peluru melalui media poa dilaksanakan pada semestergenaptahun ajaran 2017/2018.

Yang dijadikan subjek penelitian ini dalam hal ini siswakelas V SD Negeri5 Kota Bengkulu Tahun Pelajaran 2017, dengan jumlah siswa sebanyak 35 orang. Pengumpulan data penelitian ini seperti pada umumnya suatu penelitian adalah dengan menggunakan instrumen. Instrumen memegang peranan yang sangat strategis dan penting dalam menentukan kualitas suatu penelitian, adapun teknik pengumpulan data dilakukan dengan cara sebagai berikut, Observasi adalah pengamatan langsung terhadap suatu kegiatan yang sedang berjalan. Pada penelitian ini dilakukan observasi saat terjadinya proses pembelajaran keterampilan gerak dasar tolak peluru di kelas V SD Negeri 5 Kota Bengkulu yang dilakukan oleh kepala sekolah dan teman sejawat. Observasi dilakukan untuk mengetahui dan mengamati aktivitas guru dan aktivitas siswa selama kegiatan pembelajaran berlangsung. Instrumen penelitian yang digunakan untuk pengumpulan data dalam penelitian ini adalah:1).lembar observasiguru, 2).lembar observasi siswa.

\section{HASIL DAN PEMBAHASAN}

\section{Hasil}

Berdasarkan proses meningkatkan belajar siswa tolak peluru melalui media bola POA pada siswa kelas V SD Negeri 05 Kota Bengkulu pada proses belajar mengajar disiklus 1 yaitu 12 item atau mendapat presentase (40\%). Begitu juga dengan jumlah indikator yang siswa ikuti pada proses belajar mengajar disiklus ke 1 yaitu 12 item atau mendapat presentase (40\%) belum tuntas belajar.

Sedangkan penilaian tes tolak peluru sebanyak 14 siswa dimana sebesar (40\%) dan belum dinyatakan tuntas.

Pada proses belajar mengajar observasi guru di siklus ke 2 yaitu 20 item atau mendapat presentase $(66 \%)$ belum tuntas belajar. Begitu juga dengan jumlah indikator yang siswa ikuti pada proses belajar mengajar disiklus ke dua yaitu 18 item atau mendapat presentase $(60 \%)$ belum tuntas belajar. Sedangkan menilaiantes tolak peluru sebanyak 23 siswa dimana sebesar $(65,7 \%)$ dan belum dinyatakan tuntas.

Pada proses belajar mengajar observasi guru di siklus 3 peningkatan proses belajar mengajar itu dapat dilihat pada lembar observasi baik guru maupun siswa. Jumlah indikator yang guru lakukan pada proses belajar mengajardisiklus ke tiga yaitu 24 item atau mendapat presentase $(80 \%)$ telah tuntas belajar Begitu juga dengan jumlah indikator yang siswa ikuti pada proses belajar mengajar disiklus ke tiga yaitu 23 item atau mendapat presentase $(76 \%)$ telah tuntas belajar. Hasiltes tolak peluru pada siklus 3 juga meningkat menjadi $(85,7 \%)$ sebanyak 30 siswa. Berdasarkan hasil tersebut maka dapat disimpulkan bahwa penelitian ini telah mencapai standar indikator keberhasilan yang ditetapkan yaitu ( $70 \%)$. Dan bagi 6 siswa yang belum dinyatakan terlalu baik dalam mencapai ketuntasan telah disampaikan pada guru bidang studi supaya lebih diperhatikan dalam proses belajar mengajar agar mereka dapat mengimbangi teman mereka yang telah mendapatkan hasil yang baik. Maka penelitian ini dianggap selesai. 15,92

\section{Pembahasan}

Berdasarkan prosedur penelitian tindakan kelas yang sudah dirancang dan dilaksanakan dengan sistematis, peneliti dapat mengumpulkan data penelitian yang mungkin dapat berupa informasi penting dari hasil penelitian. Penerapan media bola POA dalam 
proses belajar tolak peluru memberikan dampak positip kepada siswa. Dari prosesnya observasi awal hingga pelaksanaan pada siklus 3 terjadi peningkatan pada tiap pertemuannya.

Pada observasi awal peneliti memberikan tes penilaian terhadap kemampuan tolak peluru pada siswa, namun belum diberikan materi pembelajaran tolak peluru. Hasil dari nilai tes siswa, sebagian besar belum menguasai teknik tolak peluru yang baik. Dari 35 siswa kelas V SD Negeri 05 Kota Bengkulu yang dapatperensentasidalam kategoricukup 13 siswa $(37,1 \%)$ serta siswa yang belum mampu menguasai sebanyak 22 siswa $(62,8 \%$ ). Pada proses belajar mengajar disiklus 1 yaitu 12 item atau mendapat presentase (40\%). Begitu juga dengan jumlah indikator yang siswa ikuti pada proses belajar mengajar disiklus ke 1 yaitu 12 item atau mendapat presentase (40\%) belum tuntas belajar.

Pada proses belajar mengajar observasi guru disiklus ke dua yaitu 20 item atau mendapat presentase $(66 \%)$ belum tuntas belajar. Begitu juga dengan jumlah indikator yang siswa ikuti pada proses belajar mengajar disiklus ke dua yaitu 1 item atau mendapat presentase $(60 \%)$ belum tuntas belajar.

Pada siklus 3 peningkatan proses belajar mengajar itu dapat dilihat pada lembar observasi baik guru maupun siswa. Jumlah indikator yang guru lakukan pada proses belajarmengajar disiklus ketiga yaitu 24 item atau mendapat presentase (80\%) telah tuntas belajar Begitu juga dengan jumlah indikator yang siswa ikuti pada proses belajar mengajar disiklus ke tiga yaitu 23 item atau mendapat presentase (76\%) telah tuntas belajar. Sedangkan penilaian tes tolak peluru sebanyak 14 siswa dimana sebesar (40\%) dan belum dinyatakan tuntas. Sedangkan menilaian tes tolak peluru sebanyak 23 siswa dimana sebesar $(65,7 \%)$ dan belum dinyatakan tuntas. Hasil tes tolak peluru pada siklus 3 juga meningkat menjadi $(85,7 \%)$ sebanyak 30 siswa.

\section{PENUTUP}

\section{Simpulan}

Seluruh rangkaian penelitian tindakan kelas (PTK) di SD Negeri 1 Kota Bengkulu telah selesai dilaksanakan, maka hasil penelitian dapat disimpulkan sebagai berikut:

1. Penerapan media bola poa pembelajaran dapat meningkatkan teknik tolak peluru.

2. Dari hasil tes awal yang dilaksanakan hingga tes siklus 3 menunjukkan peningkatan dimana pada tes awal tingkat ketuntasan belajar siswa secara keseluruhan sebesar 13,1\%. Pada siklus 1 meningkat menjadi $40 \%$ juga pada siklus 2 meningkat menjadi $65,7 \%$ dan pada siklus 3 meningkat menjadi $85,7 \%$ dengan artinya secara keseluruhan nilai siswa sudah mencapai KKM.

3. Dengan model pembelajaran menggunakan media poa, dapat meningkatkan kemapuan proses belajar tolak peluru, juga dapat pembelajaran ini kemauan siswa akan keberhasilan dalam belajar menjadi meningkat, sesama siswa dapat saling bertanya dan saling memotivasi siswa yang belum menguasai.

\section{Saran}

1. Bagi sekolah

Perlu adanya penyediaan fasilitas sarana dan prasarana untuk pengajaran pendidikan jasmani yang lebih lengkap oleh sekolah

2. Bagi Guru

Carilah ide-ide yang inovatif dan kreatif untuk meningkatkan kualitas belajar mengajar, ciptakanlah pembelajaran yang praktis, aktif, inovatif, efektif, dan menyenangkan gembira dan berbobot. Dalam mengajar guru harus mempunyai tujuan agar semua ranah dalam pembelajaran dapat terpenuhi.

3. Bagi siswa

Meningkatkan semangat belajar siswa dalam kondisi dan keadaan apapun, ketahuilah belajar itu sangat menyenangkan dan menjadikan diri siswalebih berprestasi, serta kembangkanlah potensi dan skil sesuai dengan apa yang dikuasai. 
4. Bagi peneliti lain

Hasil penelitian ini dapat digunakan sebagai pengembangan pada penelitian berikutnya dengan materi dan media lainya.

\section{DAFTAR PUSTAKA}

Arsyad Azhar. (2002). Media Pembelajaran. Jakarta: PT Raja Grafindo Persada

Guntur. (2009).Atletik dan Peraturanya. Jakarta: CV. Ipa Abong.

Handoyo. (2015). Upaya Meningkatkan Kemampuan Tolak Peluru Dengan Menggunakan Metode Praktis. Universitas Bengkulu.

Kunandar. (2008). Langkah Mudah Penelitian Tindakan Kelas Sebagai Pengembangan Propesi Guru. Jakarta: PT Raja Grafindo.

Lumintuarso Ria. (2009). Peralatan Olahrga Anak (POA). Jakarta.

Mujiono, Dimyati. (2013). Belajar Dan Pembelajaran. Jakarta: Rineka Cipta

Rosdiani Dini. (2013). Perencanaan Pembelajaran Dalam Pendidikan Jasmani Dan Kesehatan. Bandung: Alfabeta

Saputra Yudha M. (2001). .Pembelajaran Atletik di Sekolah Dasar. Jakarta: Direktorat Jendral Olahraga.

Sekolah Tinggi Keguruan dan Ilmu Pendidikan Dharma Wacana Metro. (2012). Atletik. Lampung: STKIP Dharma Wacana.

Sulistianta Heru. (2010). Athletics For All. Lampung: Metro.

Sutanto Teguh. (2016). Buku Pintar Olahraga.Yogyakarta: Pustaka BaruPress.

Taufik Agus, Mikarsa Hera L, Prianto Puji L. (2010). Pendidikan Anak Di SD. Undangundang No 20 Tahun 2003 Tentang sistem Pendidikan Nasional, Jakarta. 